\section{Response to: 'Biologic agents for giant cell arteritis: treat to target' by Moiseev et al}

We thank Moiseev et al for their interest in our study of ustekinumab in giant cell arteritis (GCA). ${ }^{12}$ Our pilot study reported promising initial results from the use of ustekinumab in GCA. ${ }^{1}$

GCA is a potentially devastating disease with cranial ischaemic complications such as blindness and stroke occurring in 20\%$25 \%$ of patients. ${ }^{3}$ While corticosteroids are effective in reducing the risk of cranial ischaemic complications, they do not fully extinguish the vascular inflammation in patients with $\mathrm{GCA}^{4-6}$ with consequent risk of disease relapse and longer-term consequences such as aortic aneurysms. ${ }^{78}$ Furthermore, corticosteroids are associated with significant complications in $95 \%$ of patients, including fractures, sepsis and type 2 diabetes mellitus. ${ }^{9}$ These are not benign adverse events that should be considered an acceptable trade-off for the observed partial clinical efficacy of corticosteroids. Fractures, for example, carry a $20 \%$ excess mortality after 5 years, with hip fractures having a $20 \%$ mortality after 1 year. ${ }^{10}$ Biologic agents, like any other treatment, have potential adverse events. However, the weight of evidence suggests that they are safer than long-term corticosteroids. ${ }^{11-13}$

We agree that there is a fundamental imperative for treat to target strategies in GCA. But what is the target? Currently, as there is no validated disease activity measure for GCA, patient evaluation relies on clinician assessment and acute phase reactants, which incompletely capture disease activity and progression. Large vessel imaging studies are helpful in some situations, but all have limitations and none are proven to reliably reflect disease activity upon serial imaging, particularly in patients who have been established on corticosteroid therapy. The development of a validated disease activity measure for GCA is urgently needed.

We agree with Moiseev et al that some patients with GCA may be overtreated. However, the converse is also true-many patients with GCA are undertreated, contributing to long-term disease-related complications such as thoracic aortic aneurysms, not least because of the lack of effective therapies. Key goals of new therapies in GCA should include more effective inhibition of vascular, not just systemic, inflammation and decreasing drugrelated adverse events through a reduction in corticosteroid use.

We have reported our encouraging preliminary experience with ustekinumab in patients with refractory GCA. ${ }^{1}$ However, ustekinumab requires further evaluation in randomised controlled trials and ultimately may or may not emerge as an appropriate treatment for GCA. What is clearly evident, however, is that steroid monotherapy is a suboptimal treatment strategy for many patients with GCA and ongoing efforts are required to identify safe and effective alternative therapies.

\section{Richard Conway, ${ }^{1,2}$ Eamonn S Molloy}

${ }^{1}$ Centre for Arthritis and Rheumatic Diseases, St Vincent's University Hospital, Dublin Academic Medical Centre, Elm Park, Dublin 4, Ireland

${ }^{2}$ CARD Newman Research Fellow, University College Dublin, Belfield, Dublin 4, Ireland
Correspondence to Dr Richard Conway, Centre for Arthritis and Rheumatic Diseases, St Vincent's University Hospital, Dublin Academic Medical Centre, Elm Park, Dublin 4, Ireland; drrichardconway@gmail.com

Competing interests None declared.

Provenance and peer review Not commissioned; externally peer reviewed.

Data sharing statement Data used in this study are held in Bone and Joint Unit, St Vincent's University Hospital, Dublin, Ireland under the custody of ESM and can be made available on request.

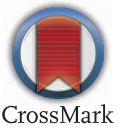

To cite Conway R, Molloy ES. Ann Rheum Dis 2016;75:e59.

Accepted 29 June 2016

Published Online First 15 July 2016

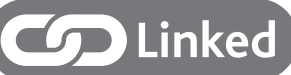

http://dx.doi.org/10.1136/annrheumdis-2016-210061

Ann Rheum Dis 2016;75:e59. doi:10.1136/annrheumdis-2016-210082

\section{REFERENCES}

1 Conway $R, O^{\prime}$ Neill L, O'Flynn E, et al. Ustekinumab for the treatment of refractory giant cell arteritis. Ann Rheum Dis 2016;75:1578-9.

2 Moiseev S, Novikov P, Meshkov A, et al. Biologic agents for giant cell arteritis: treat to target. Ann Rheum Dis 2016:75:e58.

3 Singh AG, Kermani TA, Crowson CS, et al. Visual manifestations in giant cell arteritis: trend over 5 decades in a population-based cohort. I Rheumatol 2015;42:309-15.

4 Ostberg G. Temporal arteritis in a large necropsy series. Ann Rheum Dis 1971:30:224-35.

5 Weyand $\mathrm{CM}$, Kaiser M, Yang $\mathrm{H}$, et al. Therapeutic effects of acetylsalicylic acid in giant cell arteritis. Arthritis Rheum 2002:46:457-66.

6 Fritzlen J, Younge B, Weyand CM, et al. Second temporal artery biopsies in patients with temporal arteritis. Arthritis Rheumatol 2015;67(Suppl 10): 2590-1.

7 Nuenninghoff DM, Hunder GG, Christianson TJ, et al. Incidence and predictors of large-artery complication (aortic aneurysm, aortic dissection, and/or large-artery stenosis) in patients with giant cell arteritis: a population-based study over 50 years. Arthritis Rheum 2003;48:3522-31.

8 Evans JM, O'Fallon WM, Hunder GG. Increased incidence of aortic aneurysm and dissection in giant cell (temporal) arteritis. A population-based study. Ann Intern Med 1995;122:502-7.

9 Chandran A, Udayakumar PD, Kermani TA, et al. Glucocorticoid usage in giant cell arteritis over six decades (1950 to 2009). Clin Exp Rheumatol 2015;33(Suppl 89): S-98-102.

10 Cooper $C$. The crippling consequences of fractures and their impact on quality of life. Am J Med 1997;103:12S-7S; discussion 17S-19S.

11 Widdifield J, Bernatsky S, Paterson JM, et al. Serious infections in a population-based cohort of 86,039 seniors with rheumatoid arthritis. Arthritis Care Res (Hoboken) 2013;65:353-61.

12 Grijalva CG, Chen L, Delzell E, et al. Initiation of tumor necrosis factor-alpha antagonists and the risk of hospitalization for infection in patients with autoimmune diseases. JAMA 2011;306:2331-9.

13 Richter A, Listing J, Schneider M, et al. Impact of treatment with biologic DMARDs on the risk of sepsis or mortality after serious infection in patients with rheumatoid arthritis. Ann Rheum Dis 2016;75:1667-73. 